\title{
Desain dan Pembuatan Faceshield Sebagai Alat Perlindungan Diri Penyebaran Covid19
}

\author{
Cahyo Budi Nugroho ${ }^{1}$, Ismail ${ }^{1}$, Gawan $\mathrm{S}^{\mathbf{1}}$, Abulija $\mathbf{M}^{1}$, M. Syafei $\mathrm{G}^{1}$,Asrafi ${ }^{1}$, Sapto \\ Wiratno $S^{1}$, Randi $S^{1}$, Chandra Defta Rusdwinanto ${ }^{1}$, Sriyanto ${ }^{1}$, Naufal $A P^{1}$, Meida PA ${ }^{1}$ \\ ${ }^{1}$ Polteknik Negeri Batam, Jl. Ahmad Yani, Tlk. Tering, Batam Kota, Kota Batam, Kepulauan \\ Riau 29461
}

\begin{abstract}
Kebutuhan alat pelindung diri (APD) berupa pelindung wajah mengalami kenaikan yang tajam semenjak penyebaran covid19. Virus yang dapat menular melalui media droplet tersebut dapat membahayakan tenaga kesehatan atau personal yang berinteraksi langsung dengan penderita penyakit yang disebabkan covid19. Keberadaan pelindung wajah, meskipun bukan alat pelindung satu-satunya sangat diperlukan untuk menunjang peralatan yang lain. Tanpa adanya pelindung wajah tersebut maka akan memperbesar kemungkinan penularan virus tersebut. Tujuan dari penulisan jurnal ini adalah untuk menjelaskan proses desain, pembuatan, serta rencana distribusi APD ke masyarakat. Dari proses yang dilakukan dapat disimpulkan bahwa proses produksi melalui beberapa tahapan yang melibatkan sumber daya manusia dengan kemampuan desain produk, manajerial, pengemasan dan sumber daya alat yang beragam meliputi mesin pneumatic, CNC, alat pemotong dengan laser serta desain komputer. Dari segi distribusi, pengiriman alat dilakukan dengan menggunakan berbagai espedisi darat, laut dan udara dengan area pengiriman beberapa provinsi antara lain Jawa Tengah, Jawa Timur, Jawa Barat, Sumatera Barat serta kepualauan Riau.

Kata kuci: faceshield, pelindung wajah, covid19, APD
\end{abstract}

Abstrak- The need for personal protective equipment (PPE) in the form of face protection has increased sharply since the spread of the covid19. Viruses that can be transmitted through droplet media can endanger health or personal who interact directly with sufferers of diseases caused by covid19. The existence of a face shield, even though it is not the only one protective device, is needed to support other equipment. Without the face shield, it will increase the likelihood the transmission of virus. The purpose of writing this journal is to explain the process of design, manufacture and planning of PPE distribution to the public From the process carried out it can be concluded that the production process goes through several stages involving human resources with product design, managerial, packaging ability and also diverse tool resources including pneumatic, CNC machines, laser cutting and computer. In terms of distribution, delivery of equipment is carried out using a variety of land, sea and air expeditions with location areas in several provinces including Central Java, East Java, West Java, West Sumatra and Riau Islands.

Key words: faceshield, face shield, covid19, PPE

\section{Pendahuluan}

Covid19 menyerang hampir di seluruh penjuru dunia. Hanya daerah-daerah yang benar-benar terisolasi dari interaksi dengan manusia yang terkena virus covid19 yang kemungkinan besar aman dari penyebaran virus covid 19[1]. Kebutuhan alat pelindung diri (APD) mengalami kenaikan semenjak pasien yang sakit akibat covid19 bertambah. Kebutuhan ini beralasan sebab tanpa adanya pelindung diri yang memadai, covid19 mudah sekali menyebar dan mengakibatkan sakit pada orang yang terkena virus tersebut. 


\section{Total Cases}

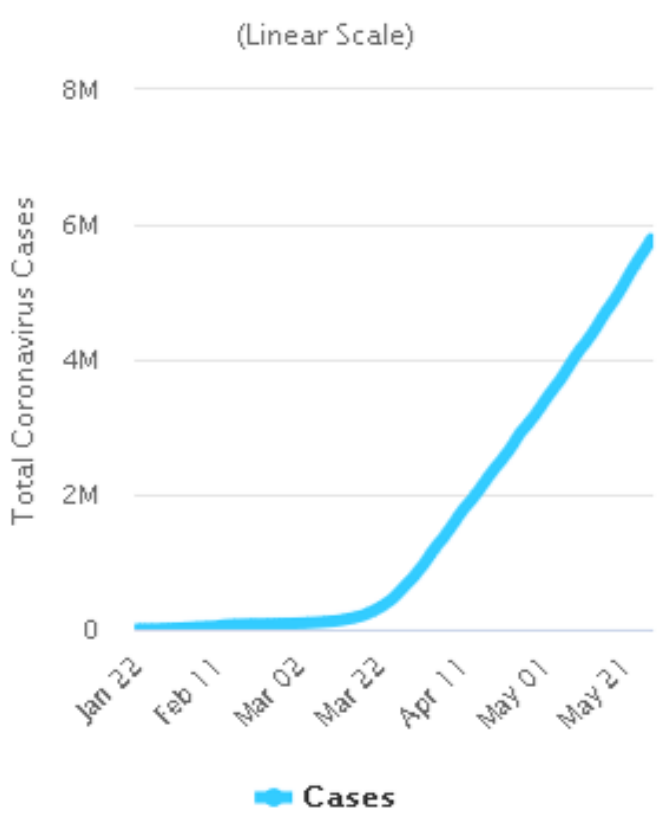

\section{Total Deaths}

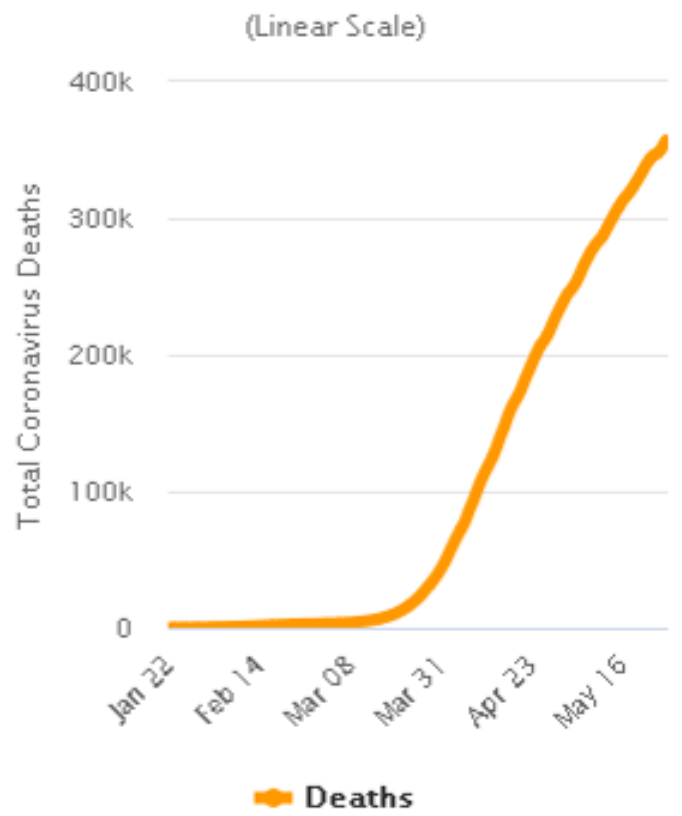

Gambar 1. Grafik Kasus Covid19 di Seluruh Dunia (sumber: www.worldometers.info > coronavirus > country)

Gambar 1 beraupa grafik menjelaskan kejadian yang awalya sangat sedikit dan hanya terjadi didaerah tertentu mengami kenaikan tajam dilihat dari kurva yang melengkung tegak setelah bentuknya landai. Data tersebut selalu terbaharui setiap 24 jam dan ketika data terebut diambil leh peneliti, perubahan sudah terjadi seirin bertambahnya daerah cakupan penderita dimana perubahan yang terjadi juga sangat massive.

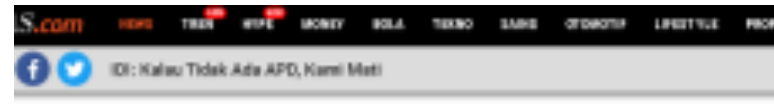

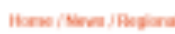

\section{IDI: Kalau Tidak Ada APD, Kami Mati}

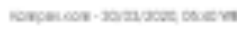

ausase $\boldsymbol{f} \bullet$

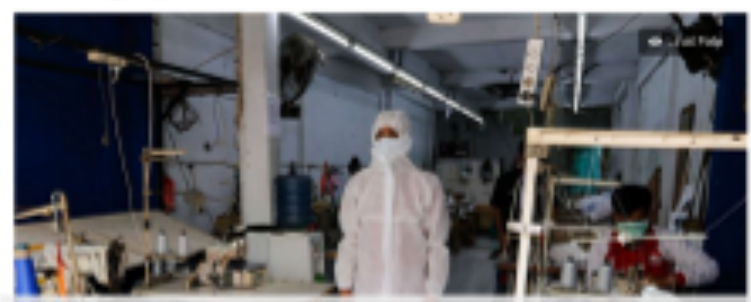

IDI: Kalau Tidak Ada APD, Kami Mati Halaman all - Kompas.com IDI: Kalau Tidak Ada APD, Kami Mati. Kompas.com - 30/03/2020, 06:40 WIB. Bagikar Komentar. Pekerja menunjukkan alat pelindung diri buatan konveksi milik

regional.kompas.com > 2020003/30 - Terjemanke koco iki

IDI: Kalau Tidak Ada APD, Kami Mati - Kompas Regional IDI: Kalau Tidak Ada APD, Kami Mati. Kompas.com - 30/03/2020, 06:40 WB. Bagikan:

Wur beritasatu com , kesehatan - Teriemahke koco ik

Soal Data 1.000 Korban Jiwa Covid-19, Ini Klarifikasi Ketua ... 23 Apr 2020 - Presiden meminta IDI membuka saja data-data yang ada.... Namun, yane kami sampaikan adalah ada tambahan data mengenai, kematian yang masih status... Kalau tes PCR tidak cepat, maka status PDP ini kita lakukan.

news.detik.com > berita > jokowi- - Teriemanke koco iki

Jokowi Minta Tak Perkeruh Suasana, IDI: Kami Ingatkan Data ... 23 Apr 2020 - Slamet awalnya menyampaikan permohonan maaf jika pengungkapan kasus kematian terkait Corona menimbulkan kegaduhan. "Jadi IDI

InI Sohıt Kamatian Cornna I ahih dari 1 nnn Knmisi IX Minta 


\section{Kekurangan APD, 3 Dokter Muslim Meninggal akibat Corona}

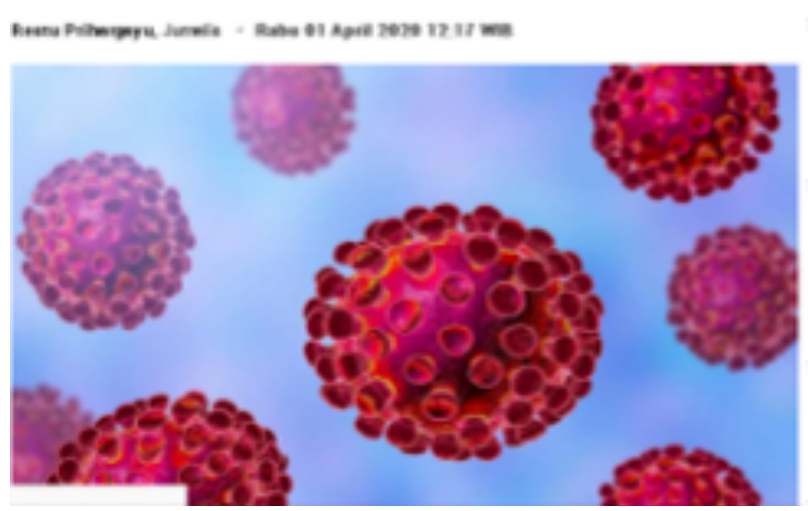

mow merdeka.com > peristiwa s id... - Terjemahke koco iki

IDI Sebut Data Kematian Covid-19 Tidak Sesuai Realita 18 Apr 2020 - IDI Sebut Data Kematian Covid-19 Tidak Sesuai Realita ... "Ada sedikit perbedaan dengan masing-masing rumah sakit, diperilhatkan data real ... rumah sakit, kala Humah sakit ini angka kematian seribu sekian, dua kall lipatnya," $\ldots$... (koma ganti titik)d tunggu yah bosku akan kami proses secpt nya bosku.

monw cnbcindonesia.com > news - Teriemahke koco iki

Angka Kematian Terkait Corona Jadi Perdebatan, Siapa Benar? 19 Apr 2020 - Jakarta, CNBC Indonesia - Kemarin, Ikatan Dokter Indonesia (IDI) ... saja, kalau data yang bukan COVID juga ada datanya, tapi yang saya ... Selain itu ia menuturkan kalau dirinya juga memiliki ...

kumparan.com > kumparansains - Terjemanke koco iki

IDI Ungkap Jumlah Dokter Meninggal Dunia Terkait Virus ... 27 Apr 2020 - TDr buka data dokter meninggal dunia yang dikaitkan dengan kasus virus coron COVID-19... PB Ikatan Dokter Indonesia (III), Daeng M. Fagih, sejauh ini ada 25 ... Jadi 25 yang dilaporkan ke kami itu, kami akan audit dan akan kami ... DP.JP tersebut, maka kemungkinan kalau terus meningkat pasien,

ung trinnews com Nows, Revionat.

Dokter IDI di Puskesmas Ketakutan: Kalau Tidak Ada APD

30 Mar 2020 - Dokter IDI di Puskesmas Ketakutan: Kalau Tidak Ada APD Mati Kami. FOTO Pekerja menunjukkan alat pelindung diri buatan konveksi milik.

Gambar 2. Pemberitaan Media Elektronik Terkait Alat Pelindung Diri

(sumber: google.com/apd corona)

Gambar di atas merupakan sedikit dari banyak media yang melaporkan minimnya APD pada penangan covid19. Yang terjadi sepertinya dalam kasus covid19 ini adalah cepatnya penyebaran, dengan jumlah penambahan tenaga dan alat medis yang tidak cukup untuk mengatasi dan menyelesaikan penyakit akibat covid19[2].

Penyebaran covid19 yang demikian tinggi, cepat dan membahayakan menggugah keinginan bagi penulis untuk melakukan kegiatan pengabdian yang dapat membantu membenahi permasalahan serta dapat mengurangi penyebaran virus dan membantu melengkapi kekurangan alat pelindung diri yang dibutuhkan oleh tenaga medis dan non medis . Fungsi dari pelindung wajah ini[3] salah satunya adalah melindungi manusia dari terkena droplet covid19. Droplet dapat diartikan sebagai cairan yang dikeluarkan dari tubuh berupa percikan yang dapat digunakan virus sebagai tempat hidup dimana penularan virus dapat berasal dari droplet tersebut. Dengan pelindung wajah ini[4], droplet yang menyebar dapat tertahan sehinga tidak langsung menyebar di udara dan membahayakan tenaga medis yang berhubungan langsung dengan pasien

\section{Tinjauan Pustaka}

Pelindung wajah adalah perangkat peralatan pelindung pribadi yang digunakan oleh banyak pekerja (misalnya tenga medis, kedoktran gigi, kedokteran hewan) untuk melindungi daerah wajah dan selaput lendir seperti pada bagian mata, hidung, mulut dari cipratan, semprotan, dan percikan cairan tubuh. Pelindung wajah umumnya tidak digunakan sendiri, tetapi bersamaan dengan peralatan pelindung lainnya dan karenanya diklasifikasikan sebagai peralatan pelindung pribadi tambahan. Terdapat bermacam-macam penggunaan perisai wajah dan semua fungsinya berbeda sesuai denga keperluan yang diinginkan[5]. 
Berbagai jenis pelindung wajah dapat dijelaskan pada penjelasan berikut. Informasi ini didasarkan pada penggunaan tipikal, namun desain terus berkembang dan kesesuaian perangkat untuk suatu tugas dapat berubah. Jenis pelindung mata dan wajah dapat dijelaskan sebagai berikut[6][7]:

Tabel 1 Jenis Pelindung Wajah dan Mata

\begin{tabular}{|l|l|l|l|}
\hline No & \multicolumn{1}{|c|}{ Nama Alat } & \multicolumn{2}{|c|}{ Penjelasan } \\
\hline 1 & Respirator Fulface & $\begin{array}{l}\text { Pelindung muka } \\
\text { yang menutup } \\
\text { seluruh bagian } \\
\text { muka dengan rapat }\end{array}$ \\
\hline 2 & Kacamata Safety & $\begin{array}{l}\text { Kacamata } \\
\text { pengaman yang } \\
\text { dilengkapi lensa } \\
\text { yang } \\
\text { benturan }\end{array}$ \\
\hline 3 & Googles & $\begin{array}{l}\text { Pelindung mata } \\
\text { yang sepenuhnya } \\
\text { melindungi mata }\end{array}$ \\
\end{tabular}




\begin{tabular}{|c|c|c|c|}
\hline No & Nama Alat & Gambar & Penjelasan \\
\hline 4 & Kacamata Hybrid & & $\begin{array}{l}\text { Sejenis kacamata } \\
\text { safety namun } \\
\text { dilengkapi } \\
\text { denagan karet } \\
\text { pelindung mata }\end{array}$ \\
\hline 5 & Helm las & & $\begin{array}{l}\text { Pelindung wajah } \\
\text { untuk melindungi } \\
\text { wajah dari sinar } \\
\text { tertentu }\end{array}$ \\
\hline 6 & Faceshield & & $\begin{array}{l}\text { Digunakan } \\
\text { bersamaan dengan } \\
\text { kacamata untuk } \\
\text { menambah tingkat } \\
\text { keamanan } \\
\text { pengguna }\end{array}$ \\
\hline 7 & $\begin{array}{l}\text { Loose-Fitiing } \\
\text { Respitaor }\end{array}$ & & $\begin{array}{l}\text { Alat yang } \\
\text { digunakan untuk } \\
\text { melindungi wajah } \\
\text { sepenuhnya } \\
\text { sampai deengan } \\
\text { bahu }\end{array}$ \\
\hline
\end{tabular}


Standar aturan Infection Prevention and Control (IPC) untuk mencegah penularan virus dalam aturan, prosedur, dan protokol layanan kesehatan perlu diterapkan. Berikut aturan efektifitas IPC secara berurutan : kontrol administrasi, lingkungan dan kontrol teknik, serta peralatan perlindungan pribadi (APD). APD[8] adalah kontrol yang paling terlihat digunakan untuk mencegah transmisi, namun harus digunakan bersamaan dengan kontrol administratif dan rekayasa (bagian keperawatan dan pekerjaan, air dan sanitasi, kebersihan tangan, pengelolaan limbah dan ventilasi). Pemilihan APD harus benar dan digunakan dengan cara yang aman; masalah keamanan sangat penting ketika APD diletakkan, dilepas atau didekontaminasi.

Praktik petugas kesehatan sama pentingnya dalam mencegah infeksi. Standar kewaspadaan adalah langkah-langkah dasar IPC. Peralatan standard yang seharusnya digunakan dalam perawatan semua pasien dapat dilihat pada Tabel 1 Peralatan tersebut dirancang untuk melindungi petugas kesehatan dan untuk mencegah infeksi menyebar kepada pasien lain. Kadang petugas kesehatan mengalami masalah untuk mengidentifikasi pasien dengan filovirus infeksi, karena gejala awal tidak spesifik. Untuk alasan tersebut maka penting bagi petugas kesehatan menggunakan tindakan pencegahan standar secara konsisten untuk semua pasien, terlepas dari diagnosis yang diberikan. Aturan yang ketat untuk tindakan pencegahan ini sangat penting untuk pengendalian wabah[9][10].

Table 2. Standar Penggunaan APD untuk Perawat

\begin{tabular}{|c|l|l|}
\hline No & \multicolumn{1}{|c|}{ Standar Pencegahan } & \multicolumn{1}{c|}{ Komponen Kunci } \\
\hline 1 & Kebersihan tangan & $\begin{array}{l}\text { Gunakan pembersih tangan yang berbasis alkohol } \\
\text { atau cuci tangan dengan menggunakan sabun }\end{array}$ \\
\hline 2 & $\begin{array}{l}\text { APD pada penanganan sakit } \\
\text { tertentu }\end{array}$ & $\begin{array}{l}\text { Gunakan APD yang sesui dan lepasakan APD } \\
\text { dengan hati-hati }\end{array}$ \\
\hline 3 & $\begin{array}{l}\text { Pencegahan pada luka tertusuk } \\
\text { jarum }\end{array}$ & $\begin{array}{l}\text { Jangan gunakan jarum secara berulang dan buang } \\
\text { jarum pada tempat yang disediakan }\end{array}$ \\
\hline 4 & $\begin{array}{l}\text { Pembersihan alat-alat yang } \\
\text { infecsius }\end{array}$ & $\begin{array}{l}\text { Lakukan pembersihan sesui dengan standar yang } \\
\text { telah ditentukan dengan maksimal dengan } \\
\text { penambahan clorin } 0,5 \%\end{array}$ \\
\hline
\end{tabular}

Pelindung wajah memiliki peranan yang penting untuk melindungi petugas kesehatan dalam menangani pasien[11][12]. Meskipun bukan alat utama, hanya sebagai pelengkap, namun peralatan ini sangat penting digunakan untuk menghindari hal yang tidak diinginka. Material 
yang digunakan juga tidak menggunakan material yang sembarang, perlu ada syarat khusus. Berikut ini disampaikan hal yang terkait dengan standar penggunaan pelindung wajah:

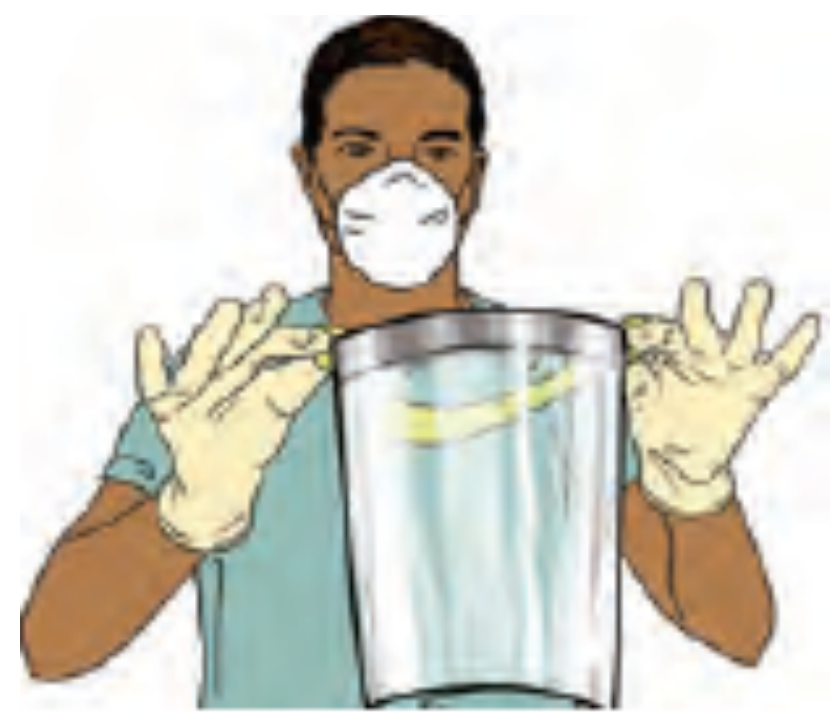

Gambar 3. Pelindung Wajah

$\checkmark$ Terbuat dari plastik bening dan memberikan visibilitas yang baik untuk pemakainya dan pasien.

$\checkmark \quad$ Pita yang bisa diatur agar pas di kepala dan pas di dahi.

$\checkmark$ Tahan kabut (lebih disukai).

$\checkmark$ Sepenuhnya menutupi sisi dan panjang wajah.

$\checkmark$ Dapat digunakan kembali (terbuat dari bahan yang dapat dibersihkan dan didesinfeksi) atau sekali pakai.

Pelindung wajah adalah APD yang biasanya digunakan sebagai pelindung untuk tujuan pengendalian infeksi oleh banyak pekerja. Saat ini tidak ada standar mengenai perlindungan wajah / mata dari bahaya biologis dan hal ini perlu diteliti secepat mungkin. Karena kurangnya segel wajah yang bagus secara periferal yang memungkinkan penetrasi aerosol, pelindung wajah tidak boleh digunakan sebagai pelindung wajah / mata soliter, melainkan sebagai tambahan untuk APD lainnya (masker pelindung, kacamata pelindung, dll.).

\section{METODE}

Metode yang dilakukan dalam pembuatan jurnal pengabdian ini adalah sebagai berikut 


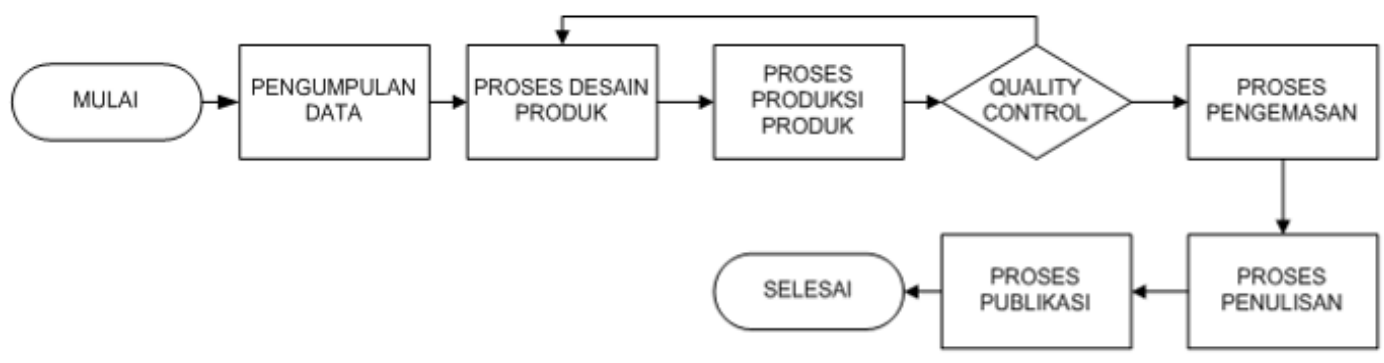

Gambar 4. Diagram Alir Metode Penulisan Pengabdian Masyarakat

Proses dimulai dengan melakukan pengumpulan data. Data yang dimaksud adalah jumlah puskesmas, lokasi puskesmas, perkiraan awal kebutuhan yang diperlukan serta kebutuhan permintaan pemenuhan. Ukuran pelindung wajah, desain pelindung wajah yang sudah ada juga dikumpulkan sehingga diperoleh referensi desain pembuatan pelindung wajah. Data lain yang diperlukan adalah jumlah dana yang sekiranya dibutuhkan dan asal penggunaan dana sehingga ketika dikerjakan, semuanya dapat diselesaiakan sesuai dengan perencanaan.

Langkah desain produk adalah proses melakukan perancangan produk dengan menggunakan perangkat lunak. Penggunaannya dilakukan oleh orang yang sudah ahli dalam melakukan desain dengan menggunakan perangkat lunak yang masih tergabung dalam anggota team. Proses desain ini memerlukan banyak pertimbangan baik dari segi keamanan, kenyaman maupun kemudahan penyimpanan serta penggunaan oleh calon pengguna.

Proses produksi merupakan tahapan yang harus dilewati untuk membuat produk jadi. Tahap produksi ini menggunakan operator yang tergabung dalam tim serta memiliki kapaistas unruk menggunakan alat dengan baik dan benar. Alat yang digunakan dalam pembuatan produk ini antara lain: mesin $C N C$, mesin pneumatic mesin laser cutting, driyer (pemanas) serta perangkat sederhana: martil, gunting, cutter, untuk proses akhir.

Tahap quality control adalah pemeriksaan kelaikan produk. Pada tahap ini produk diuji untuk kemudian dilakukan review. Jika dapat digunakan maka produk akan terus diproduksi secara masal, namun adakalanya ternyat kesalahan maka perbaikan dimulai dari proses desain.

Proses pengemasan merupakan proses yang sederhana dimana produk dimasukkan ke dalam kotak untuk selanjutnya dikirim sesuai dengan tujuan yang direncanakan. Proses pengemasan meskipun sederhana perlu kehati-hatian sebab produk yang dikirim memiliki kemungkinan untuk rusak diperjalanan sehingga dalam pengemasannya diperlukan pelaksanaan yang ketat dan tepat.

Proses berikutnya adalah melakukan penulisan jurnal. Dari seluruh kegiatan kemudian dilakukan penulisan untuk menyampakaan hasil pengabdian masyarakat kepada khalayak sehingga dapat dimengerti hal yang telah dilakukan dan dijadikan pembelajaran. 


\section{HASIL DAN PEMbahasan}

Proses yang dilakukan dalam pengabdian melalui beberapa langkah dan tahapan dimana tahapan tersebut dilakukan secara berurutan dan dengan mekanisme yang saling berkaitan satu dengan yang lain. Proses pengabdian melibatkan mesin yang berbeda dan melibatkan beberapa orang yang memiliki keahlian berbeda untuk menghasilkan produk yang maksimal. Ada yang ahli dalam bidang desain, ada yang ahli dalam bidang manufaktur, ada yang ahli dalam bidang elektronika, desain produk dan sebagianya. Berikut aliran proses pengerjaan pelindung wajah Politeknik Negeri Batam:

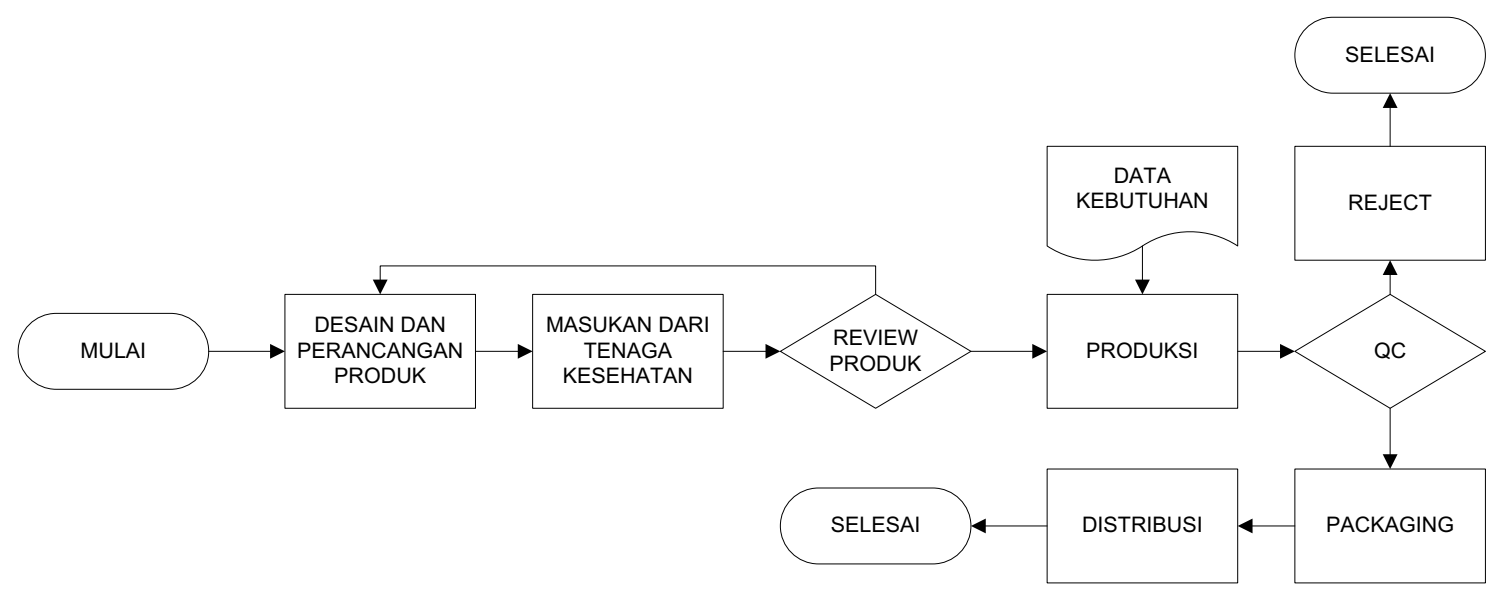

Gambar 5. Alur Proses Pengerjaan Produk

Melakukan desain dan perancangan produk sebagai gambara awal sebelum dilakukan produksi. Proses desain ini dilakukan dengan cara mencari referensi kemudian juga dilakukan ujicoba sederhana untuk mengetahui sejauh mana potensi serta kelebihan produk yang akan diproduksi. Proses berikutnya adalah mendengarkan masukan dari tenaga kesehatan. Hal ini perlu dilakukan mengingat pelindung wajah ini akan digunakann oleh tenaga medis sehingga perlu masukan untuk mengetahui batasan keamanan, kenyamanan yang diperlukan oleh pengguna ini nantinya. Review produk dilakukann guna menyimulkan apakah alat layak untuk diproduksi dan dibuat secara missal. Dengan adanya review ini, maka akan diketahui hal apa aja yang perlu ditambahkan, kekurangan apa yang harus diperbaiki untuk memaksimalkan hasil pembuatan produk.

Proses Produki adalah proses pembuatan benda untuk kemudian dilakukan pembuatan dengan jumlah banyak dan sesuai dengan yang direncanakan. Proses produksi dilakukan dengan menggunakan beberapa mesin produksi yang dimiliki oleh Jurusan Teknik Mesin diantaranya adalah mesin $\mathrm{CNC}$, mesin laser cutting, mesin punch pneumatic. Penggunaan mesin tersebut dilakukan oleh operator yang sudah berpengalaman dan sesuai dengan kompetensinya. 
Langkah berikutnya adalah melakukan proses pengecekan quality untuk memastikan produk dapat digunakan dengan baik. Jika produk dinyatakan layak pakai maka langkah selanjutnya produk akan diteruskan ke proses selanjutnya, jika tidak maka produk akan direject dan dibuang. Setelah dilakukan produksi, barang yang memenuhi standar akan dilakukan proses pengepakan dan selanjutnya barang akan dikirim seseuai dengan alamat tujuan.

\subsection{Proses Desain}

Proses pembuatan desain menggunakan perang lunak CAD (Computer Aided Design). Penggunaan software ini bertujuan untuk memperoleh gambaran singkat mengenai produk yang akan dibuat. Selain itu juga untuk memperhitungkan kebutuhan material yang akan digunakan pada proses pembuatan bagian produk pelindung wajah

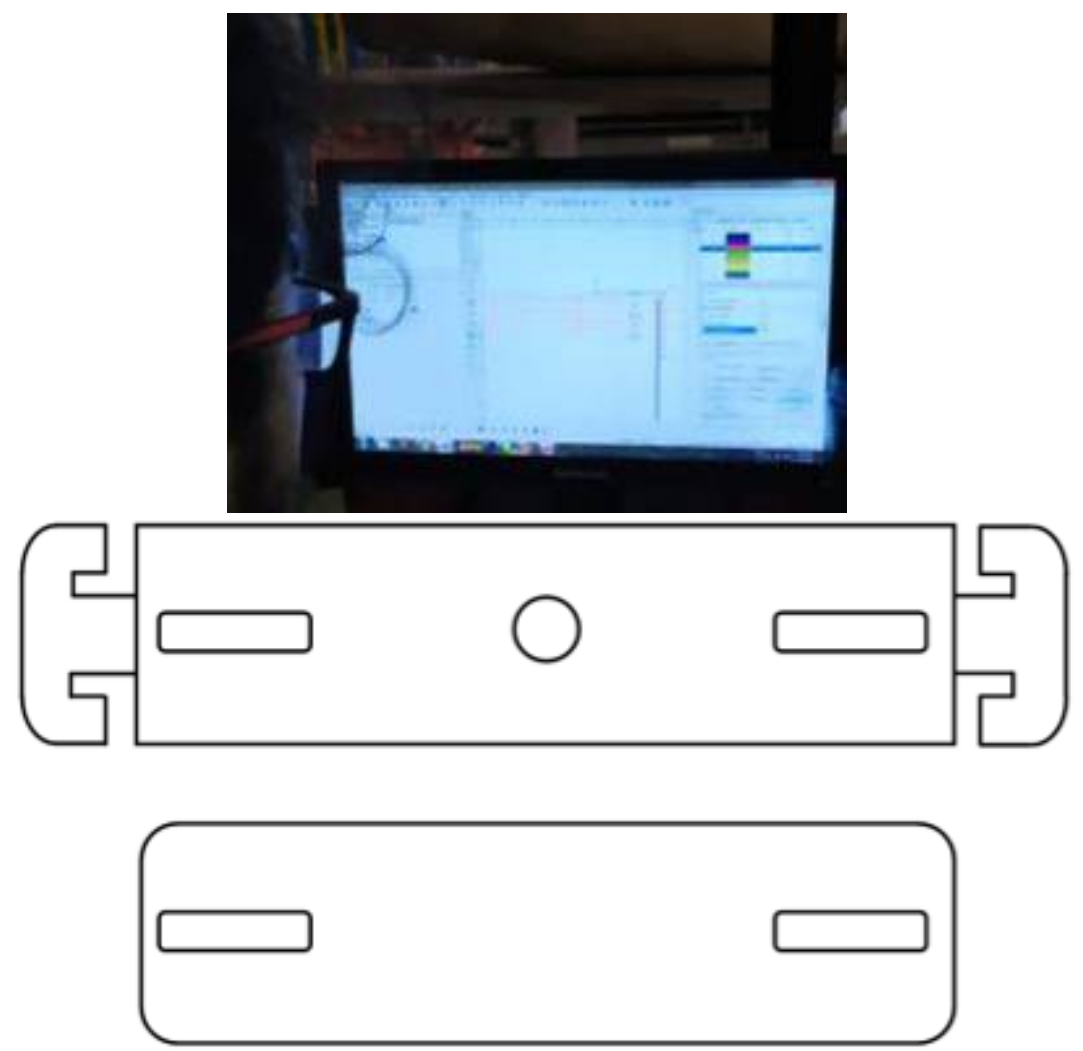

Gambar 6. Proses Desain dan Gambar Desain Menggunakan Perangkat Lunak CAD

\subsection{Proses Produksi}

Setelah proses desain selesai maka langkah berikutnya adalah dengan melakukan proses produksi. Produksi diawali dengan memindahakan file desain ke dalam mesin CAM (Computer Aided Manufacture). Mesin CAM merupakan mesin yang dapat menerjemahkan gambar desain untuk membuat gambar jadi. Mesin CAM banyak diaplikasikan di dalam dunia industry utnuk mempermudah dan mengerjakan sebuah produk. Untuk jenis mesin CAM sendiri ada banyak. 
Mesin CAM yang digunakan kali ini menggunakan mesin yang dapat memotong benda kerja. Nama alat dari mesin CAM ini adalah laser cutting. Mesin laser cutting ini adalah mesin yang menggunakan laser untuk memotong benda kerja. Cara kerjanya, benda kerja dipasang pada mesin laser cutting kemudia diletakkan di tempat yang siap dipotong. Data dari mesin CAD dipindahkan ke dalam memori mesin CAM untuk selanjutnya dilakukan eksekusi untuk memoton benda kerja. Dimensi, bentuk, dan hasil benda /produk, hasilnya akan sama persis dengan perencanaan jika pengaturan parameter, lingkungan dilakukan dengan tepat dan sesuai.
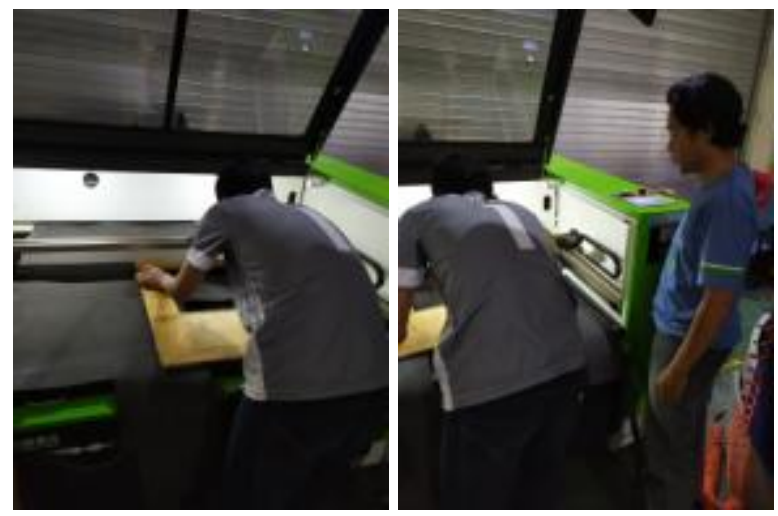

Gambar 7. Proses meletakkan benda kerja ke dalam mesin Laser Cutting

Terdapat beberapa hasil dari penggunaan mesin lase cutting tersebut antara lain sebagai berikut:

- Pemegang Mika

Pemegang mika berfungi untuk memegang mika agar tidak jatuh. Pengaturannya cukup sederhana yaitu cukup memasangkan mika pada pemegang mika kemudian mengencangkannya menggunakan baut.

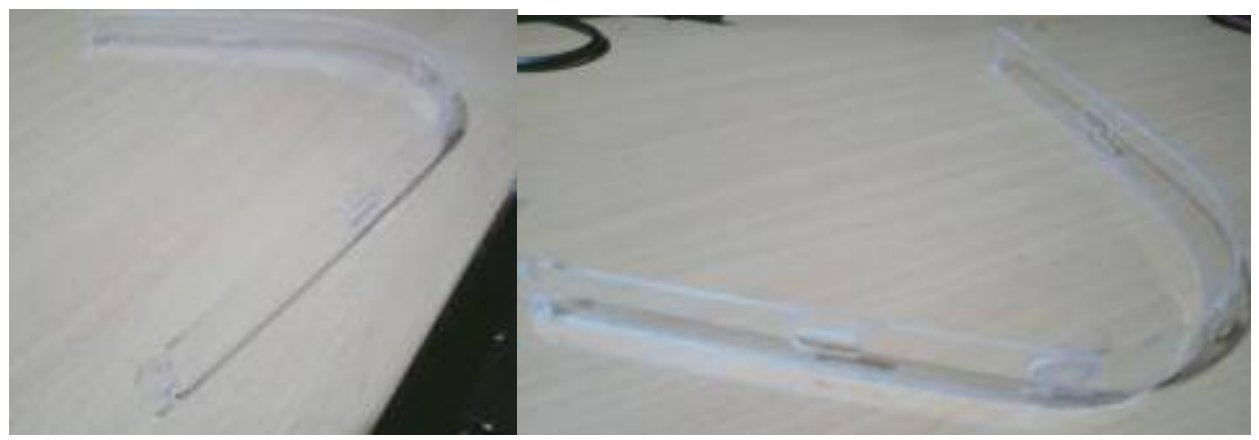

Gambar 8. Hasil Pemotongan Produk Laser Cutting (Pemegang Mika)

\section{- Pemegang Kepala}

Pemegang kepala ini merupakan bagian dari alat yang melekat dikepala yang berfungsi untuk meletakkan alat terebut di kepala pengguna. Pemegang kepala ini delangkapi dengan karet agar nyaman di kepala pengguna jika akan dipakai dalam jangka waktu yang lama. 


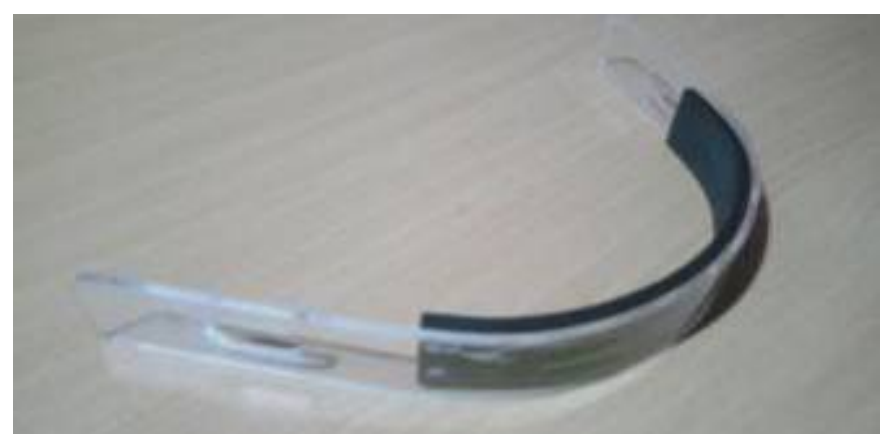

Gambar 9. Hasil Pemotongan Produk Laser Cutting Pemegang Kepala

\section{- Pembelian Baut dan Mur}

Baut yang digunakan adalah baut dengan ukuran M16 dimana baut ini berfungsi untuk mengikat dan merekatkan mika dengan pemegang kepala dan pemegang mika. Jumlah baut yang diunakan adalah tiga buah dan sepasang dengan mur.. Untuk pemilihan baut dipilih baut yang tidak bersisi sehingga nyaman ketika akan digunakan

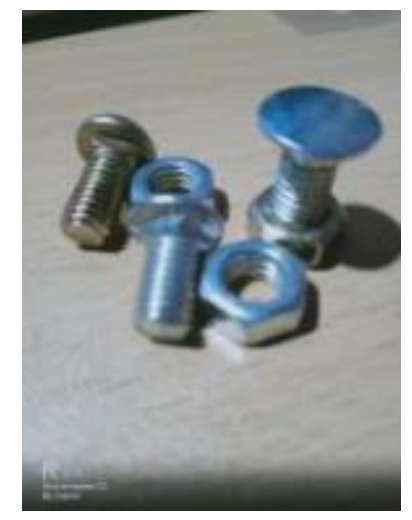

Gambar 10. Baut dan Mur

\section{- Mika Bening}

Fungsi dari mika bening adalah untuk melindungi wajah dari percikan cairan tubuh pasien sehingga tidak mengenai wajah. Pemilihan mika juga menjadi faktor penting sebab jika tidak sesuai akan mengakibatkan si pemakai mengalami pusing dan ketidaknyamanan. 


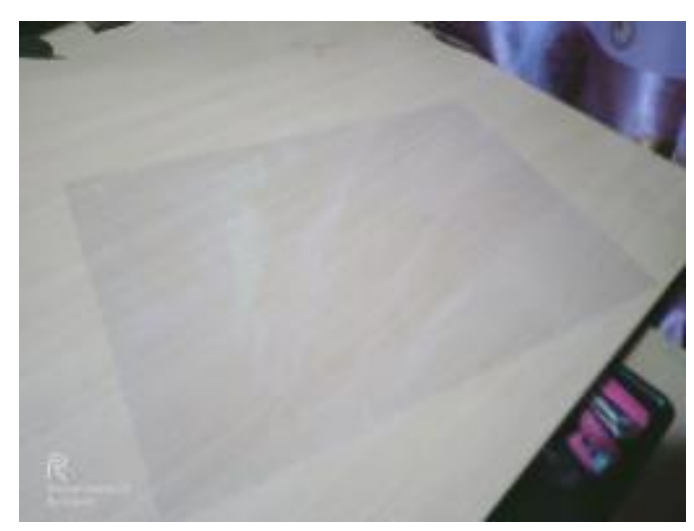

Gambar 11. Mika Bening

\section{- Karet Elastis}

Karet elastis berfungsi untuk merekatkan faceshield sehingga nyaman pas ketika dikenakan dan ttidak longgar. Hal ini penting mengingat jika longar maka faceshield akan todak nyaman ketika dikenakan.

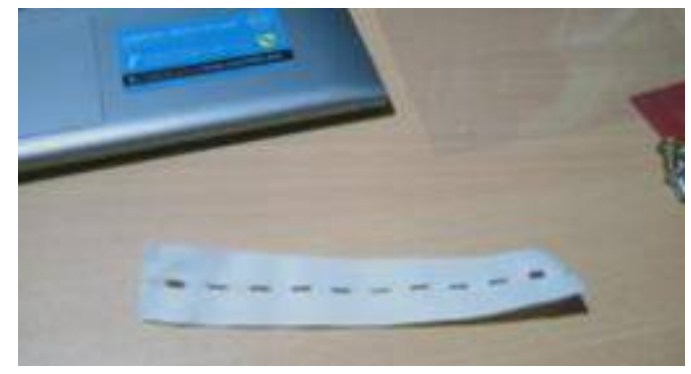

Gambar 12. Karet Elastis

Setelah bagian-bagian tersebut diproduksi, dibeli dan disediakan, langkah berikutnya adalah dengan melakukan proes assembly. Proses assembly adalah proses penggabungan komponen yang dibuat, dibeli menjadi satu barang utuh yang dapat dimanfaatkan. Untuk prosesnya memerlukan kehati-hatian sebab jika tidak maka dapat menyebabkan bagian yang dibuat bisa patah atau rusak.

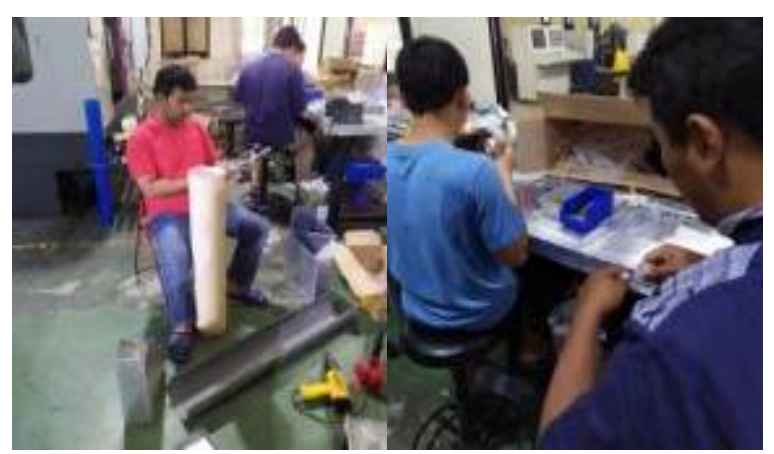

Gambar 13. Proses Assembly Pelindung wajah 
Proses assembly memerlukan kehati-hatian karena sifat material yang sudah terkena panas biasanya akan berubah menjadi mudah patah atau rusak. Dalam pemasangannya melibatkan dosen, alumni dan pakar dari beberpa industri.

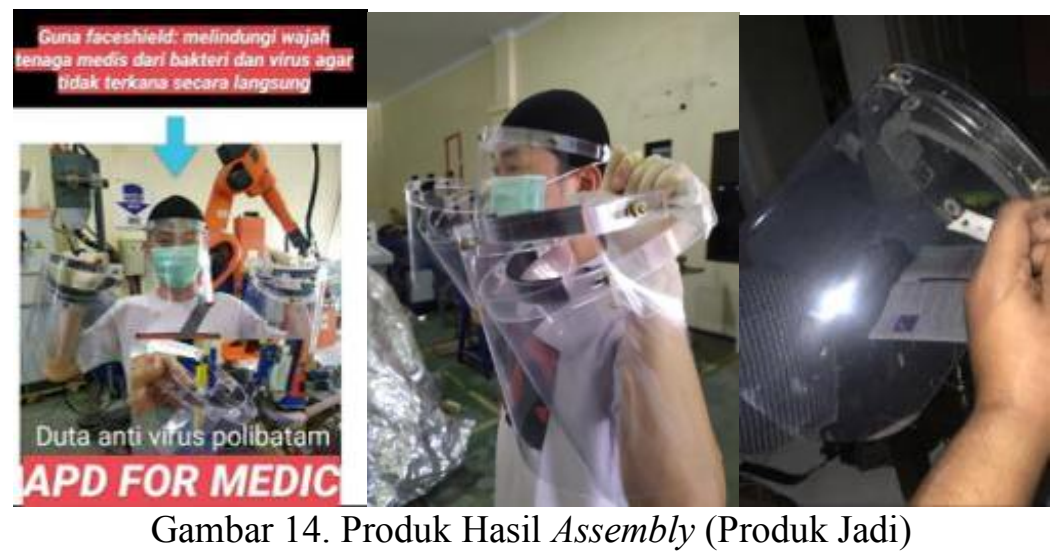

\subsection{Proes Distribusi}

Proses distribusi dilakukan dengan mengirimkan produk ke fasilitas atau unit kesehatan yang ada di Batam (utamanya) dan seluruh Indonesia pada umumnya. Permintaan tersebut dapat dilihat dari tabel berikut.

Tabel 3. Jumlah Distribusi Pelindung Wajah (Update: 7 April 2020)

\begin{tabular}{|c|l|c|}
\hline No & \multicolumn{1}{|c|}{ Pemesan } & Jumlah \\
\hline 1 & Persatuan Insiyur Indonesia & 50 \\
\hline 2 & RSUD Karimun & 6 \\
\hline 3 & Puskesmas Payakumbuh & 12 \\
\hline 4 & RS Embung fatimah & 24 \\
\hline 5 & RS Bintan & 4 \\
\hline 6 & RS Bandung & 8 \\
\hline 7 & RS PKU Muhammadiyah Surakrta & 4 \\
\hline 8 & Politeknik Negeri Banyuwangi & 100 \\
\hline
\end{tabular}

Permintaan tersebut selalu bertambah setiap harinya dan mnegalami peningkatan disebabkan jumlah pasien yang bertambah setiap harinya. Kendala terbesar dari pengiriman barang dari Batam adalah biaya ongkos pengiriman dikarenakan setiap pengiriman dari Batam akan dikenakan pajak tambahan dimana pajak tersebut tentu saja akan menaikkan harga, ataupun kalau tidak akan menyebabkan timbulnya biaya lain yang selain dari biaya produksi.

\subsection{Publikasi}

Publikasi ini adalah pelengkap dan bukti bahwa pengabdian ini dilakukan kepada masayarakt. Fungsinya adalah membritahukan kepada khalayak bahwa pemesanan dan pembuatan dapat 
dilakukan kepada Politeknik Negeri Batam dan Politenik Negeri Batam siap membantu berjuang bersama melawan covid19

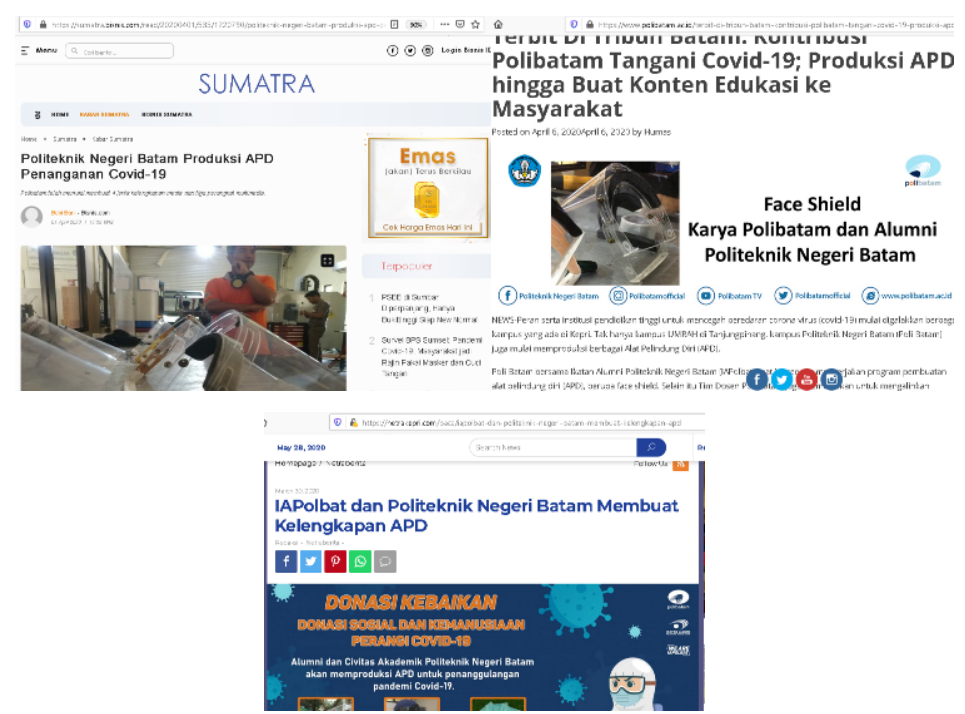

Gambar 15. Publikasi Kegiatan di Media Elektronik

\section{KESIMPULAN}

Kesimpulan dari penabdian yang dilakukan ini bahwa proses produksi melalui beberapa tahapan yang melibatkan sumber daya manusia dengan kemampuan desain produk, manajerial, pengemasan dan sumber daya alat yang beragam meliputi mesin pneumatic, CNC, alat pemotong dengan laser serta desain komputer. Dari segi distribusi, pengiriman alat dilakukan dengan menggunakan berbagai espedisi darat, laut dan udara dengan area pengiriman beberapa provinsi antara lain Jawa Tengah, Jawa Timur, Jawa Barat, Sumatera Barat

\section{UCAPAN TERIMA KASIH}

Ucapan terimakasih kami haturan sebanyak-banyaknya kepada Allah SWT, kepada Politeknik Negeri Batam, Kepada Team Pengabdian, Kepada Donatur dan Relawan serta siapapun yang terlibat yang mungkin belum disebutkan.

\section{DAfTAR PUStaka}

[1] "Personal Protective Equipment For COVID-19," hal. 2020, 2020.

[2] Direktorat Jenderal Pencegahan dan Pengendalian Penyakit, Pedoman Pencegahan dan Pengendalian Coronavirus Diseases (Covid-19). Kementrian KEsehatan RI, 2020.

[3] P. Diploma, I. I. I. Hiperkes, D. A. N. Keselamatan, F. Kedokteran, dan U. Sebelas, “TERHADAP TENAGA KERJA DI PT BAYER INDONESIA-,” 2010. 
[4] WHO, "Penggunaan Rasional Alat Perlindungan Diri untuk Penyakit Coronavirus ( COVID-19 ) dan Pertimbangan Jika Ketersediaan Sangat Terbatas.” WHO, hal. 34, 2020.

[5] R. J. Roberge, "Face shields for infection control : A review," vol. 13, no. 4, hal. 235$242,2017$.

[6] U. S. E. Guide, "EYE AND FACE PROTECTION."

[7] MENTERI dan T. K. D. T. R. INDONESIA, PERATURAN MENTERI TENAGA KERJA DAN TRANSMIGRASI TENTANG ALAT PELINDUNG DIRI. Indonesia, 2010, hal. 7.

[8] R. Wahyutomo, “ALAT PELINDUNG DIRI Tinjauan Konsep Dasar,” no. April, hal. 024, 2020.

[9] "Personal protective equipment."

[10] Direktorat Jenderal Pelayanan Kesehatan Republik Indonesia, "Petunjuk Teknis Alat Pelindung Diri (APD),” no. April, Jakarta, hal. 39, 2020.

[11] D. Apd, "Alat pelindung diri."

[12] Standar Alat Pelindung Diri (APD) Dalam Manajemen Penanganan Covid19. Jakarta: Direktorat Jenderal Kefarmasian dan Alat Kesehatan Kementrian Kesehatan RI, 2020. 